\title{
Stable isotope and scat analyses indicate diet and habitat partitioning in northern fur seals Callorhinus ursinus across the eastern Pacific
}

\author{
Tonya K. Zeppelin*, Anthony J. Orr
}

\begin{abstract}
National Marine Mammal Laboratory (NMML), Alaska Fisheries Science Center (AFSC), National Oceanic and Atmospheric Administration, 7600 Sand Point Way NE, Seattle, Washington 98115, USA
\end{abstract}

\begin{abstract}
We used stable isotope (SI) and scat analyses to describe and compare the foraging ecology of northern fur seals Callorhinus ursinus from different rookeries throughout their North American range, including rookeries on the following islands: Bogoslof Island (BI), Alaska; Reef and Vostochni on St. Paul Island (SPI), Alaska; and San Miguel Island (SMI), California. SI samples were collected from 36 adult females and 37 juveniles in Alaska, and 9 adult females and 7 pups on SMI during fall 2006. Isotopic analyses of blood and fur indicated differences in stable carbon $\left(\delta^{13} \mathrm{C}\right)$ and nitrogen $\left(\delta^{15} \mathrm{~N}\right)$ isotope values within an individual, between age classes, and among locations. At all sites, adult females generally had higher $\delta^{13} \mathrm{C}$ compared to their younger conspecifics for all tissues, suggesting that they forage in different locations. Mean $\delta^{15} \mathrm{~N}$ values of adult females were lower compared to those of pups at SMI, higher than those of juveniles on SPI, and similar to those of juveniles on BI, suggesting differences in trophic level between age classes at all locations except on BI. We found differences in $\delta^{13} \mathrm{C}$ values at all islands, suggesting that animals at each location forage in different oceanic domains. The $\delta^{15} \mathrm{~N}$ values of all age classes indicated that animals at SMI and Vostochni feed at similar trophic levels within their respective communities, but feed at higher trophic levels than animals at Reef and BI. Scat analysis supported SI results in that animals from each location were found to feed on species associated with unique oceanic features. By using scat and SI analyses, we were able to acquire a better understanding of the foraging ecology of different-aged conspecifics from multiple locations.
\end{abstract}

KEY WORDS: Callorhinus ursinus $\cdot$ Diet $\cdot$ Habitat $\cdot$ Northern fur seal $\cdot$ Scat $\cdot$ Stable isotopes Resale or republication not permitted without written consent of the publisher

\section{INTRODUCTION}

Pinnipeds are top predators in many marine ecosystems and understanding their foraging ecology is essential in determining their impacts on prey species, their interactions with fisheries, and in monitoring the health of the ecosystem (Boyd \& Murray 2001, Reid \& Croxall 2001, Arim \& Naya 2003). To accurately assess the diet of wide-ranging pinniped species that utilize diverse marine habitats, it is necessary to examine their foraging ecology over different spatial and temporal scales.

Traditionally, pinniped diet has been determined from the identification of prey hard parts collected from stomach, colon, spewing (regurgitation) or scat (fecal) samples (e.g. Lucas 1899, Antonelis \& Perez 1984, Sinclair et al. 1994, Yonezaki et al. 2003, Gundmundson et al. 2006, Zeppelin \& Ream 2006, Yonezaki et al. 2008). This technique is useful because it provides information on specific prey species consumed; however, several biases and limitations must be accounted for when using this method (see reviews by Bigg \& Fawcett 1985, Pierce \& Boyle 1991, Bowen 2000). Additionally, unless samples are collected continuously over long periods, this analysis represents only a 'snapshot' of prey consumed during an animal's most recent meal(s) and does not provide integrated, long-term foraging information (Hobson et al. 1997a). When using scats, ancillary information about the individual animal (e.g. age and sex) is not readily avail- 
able, making intraspecific dietary comparisons difficult. Most scat samples have been collected from breeding sites and primarily represent the diet of reproductive females; the diets of other age or sex classes have been examined infrequently.

More recently, pinniped foraging ecology has been examined using biochemical methods, such as measuring the abundance of naturally occurring stable isotope ratios of carbon $\left({ }^{13} \mathrm{C} /{ }^{12} \mathrm{C}\right)$ and nitrogen $\left({ }^{15} \mathrm{~N} /{ }^{14} \mathrm{~N}\right)$ (e.g. Hobson et al. 1997a, Burns et al. 1998, Burton \& Koch 1999, Hirons et al. 2001, Kurle \& Worthy 2001, Kurle 2002, Zhao et al. 2004, Newsome et al. 2006, Porras-Peters et al. 2008). Stable isotope analysis is based on the premise that the stable isotope composition of a consumer's diet is reflected in its tissues. Consumer tissues usually become enriched in ${ }^{15} \mathrm{~N}$ and ${ }^{13} \mathrm{C}$ compared to their prey due to the process of fractionation. ${ }^{15} \mathrm{~N}$ is enriched predictably with increasing trophic level due to the preferential excretion of ${ }^{14} \mathrm{~N}$ ( 2 to $5 \%$ for marine mammals; Hobson et al. 1996, Kelly 2000, Kurle 2002, Zhao et al. 2006); this permits estimation of a consumer's trophic level (Wada et al. 1991, Hobson \& Welch 1992, Gannes et al. 1998, Vander Zanden \& Rasmussen 2001). The ratio of stable carbon isotopes changes little with trophic position ( 0.5 to $2 \%$ for marine mammals; Kelly 2000, Kurle 2002, Lesage et al. 2002, Zhao et al. 2006); rather, it is affected by factors that act at the base of the food web. Stable carbon isotopes can therefore be used to estimate a consumer's foraging location (e.g. $\delta^{13} \mathrm{C}$ enrichment: nearshore > offshore, benthic > pelagic; Rau et al. 1982, Fry \& Sherr 1984, Wada et al. 1991, France 1995, Hobson et al. 1997a, Burton \& Koch 1999, Kelly 2000). Because tissues are collected in stable isotope analysis, information about the individual (e.g. age class, sex) is known and intraspecific comparisons can be made. Additionally, stable isotope analysis of tissues can provide information on assimilated diet at varying temporal scales due to the dissimilar isotopic turnover rates of different tissues (Kirsch et al. 2000). However, stable isotope analysis does not provide detailed information on dietary composition and the results from analyses can be difficult to interpret.

The northern fur seal Callorhinus ursinus is widely distributed in the North Pacific Ocean, Bering Sea, Sea of Okhotsk and Sea of Japan. It is one of the most prolific otariid pinnipeds, with abundance estimates of 1.1 million (Reeves et al. 2002, Gelatt \& Lowry 2008). In North America, most individuals of the species breed on the Pribilof Islands (St. George and St. Paul) in the southeastern Bering Sea, and this population has undergone substantial declines during the past decade (Towell et al. 2006). Conversely, smaller populations within their North American range, including those on Bogoslof and San Miguel Islands, have experienced increases since the 1980s (Ream et al. 1999, Towell et al. 2006, Melin et al. 2007).

Northern fur seals utilize diverse marine habitats over varying spatial and temporal scales. Adult females and juveniles from the Pribilof and Bogoslof Islands migrate south onto the continental shelf and slope of the eastern North Pacific Ocean, ranging as far south as $30^{\circ} \mathrm{N}$ (Lander \& Kajimura 1982, Ream et al. 2005). Animals from San Miguel Island migrate north along the continental margin to waters as far north as Queen Charlotte Islands, Canada $\left(53^{\circ} \mathrm{N}\right.$; National Marine Mammal Laboratory [NMML] unpubl. data). Northern fur seals begin their return migrations during spring and arrive at breeding colonies during early summer (Antonelis \& Perez 1984). While on breeding colonies, both adult female and juvenile male northern fur seals are central place foragers (Robson et al. 2004, Sterling \& Ream 2004, Call et al. 2008). After a 7 to $10 \mathrm{~d}$ perinatal period, adult females alternate between feeding at sea for 3 to $9 \mathrm{~d}$ and nursing their pups on land for 1 to $2 \mathrm{~d}$ (Bartholomew \& Hoel 1953, Peterson 1966, DeLong 1982, Gentry \& Holt 1986, Reeves et al. 1992). This nursing behavior is repeated $\sim 10 \times$ over the next $4 \mathrm{mo}$, after which pups are weaned and must feed for themselves (Peterson 1966). Several authors have noted that adult female fur seals exhibit fidelity to feeding areas on subsequent trips to sea (Loughlin et al. 1987, Robson et al. 2004, Call et al. 2008). Pups develop their swimming and diving skills during the nursing period (Baker \& Donohue 2000). After an abrupt weaning, pups migrate to sea where they might spend the next 2 to $3 \mathrm{yr}$ of their lives. Juveniles are not restricted in their attendance to the rookery. Differences in their morphology, physiological capabilities and experience may lead to differences in their diet, distribution, and habitat use compared to older conspecifics.

The objectives of this study were to combine scat and stable isotope analyses to examine the foraging ecology of northern fur seals across their North American range of breeding sites. Specifically, we determined whether foraging habitat and diet differed with time of year, breeding site, or age class. We used stable isotope analysis to examine temporal and age class differences, and scat analysis to identify specific prey items consumed. We compared our results with previous diet and telemetry studies at the breeding colonies.

\section{MATERIALS AND METHODS}

Study sites and sample collection. This study was conducted at 4 breeding colonies that span the geographic range of northern fur seals in North America, including rookeries on the following islands: Bogoslof 
Island (BI), Alaska $\left(53.93^{\circ} \mathrm{N}, 168.03^{\circ} \mathrm{W}\right)$; Reef and Vostochni on St. Paul Island (SPI), Alaska $\left(57.18^{\circ} \mathrm{N}\right.$, $\left.170.27^{\circ} \mathrm{W}\right)$; and San Miguel Island (SMI), California $\left(34.03^{\circ} \mathrm{N}, 120.44^{\circ} \mathrm{W}\right)$ (Fig. 1). The study sites include diverse habitats associated with distinct oceanographic features that affect the distribution and dynamics of prey resources (Stabeno et al. 1999). Additionally, recent telemetry and dietary studies from scat analysis have indicated intraspecific differences in foraging behaviors among sites included in this study (Robson et al. 2004, Zeppelin \& Ream 2006, Call et al. 2008, NMML unpubl. data).

From September through November 2006, fur and blood samples were collected from juvenile and adult female northern fur seals from BI and SPI rookeries for stable isotope analysis. Most juveniles were estimated to be 1 or 2 yr old based on morphological and behavioral characteristics (Scheffer 1962). Tissues were collected from pup and adult female fur seals at SMI during November 2006. Fur was collected from individuals by using scissors to cut a patch of guard hair $(\sim 2 \times 2 \mathrm{~cm})$ on the dorsal side at the pelvic girdle.

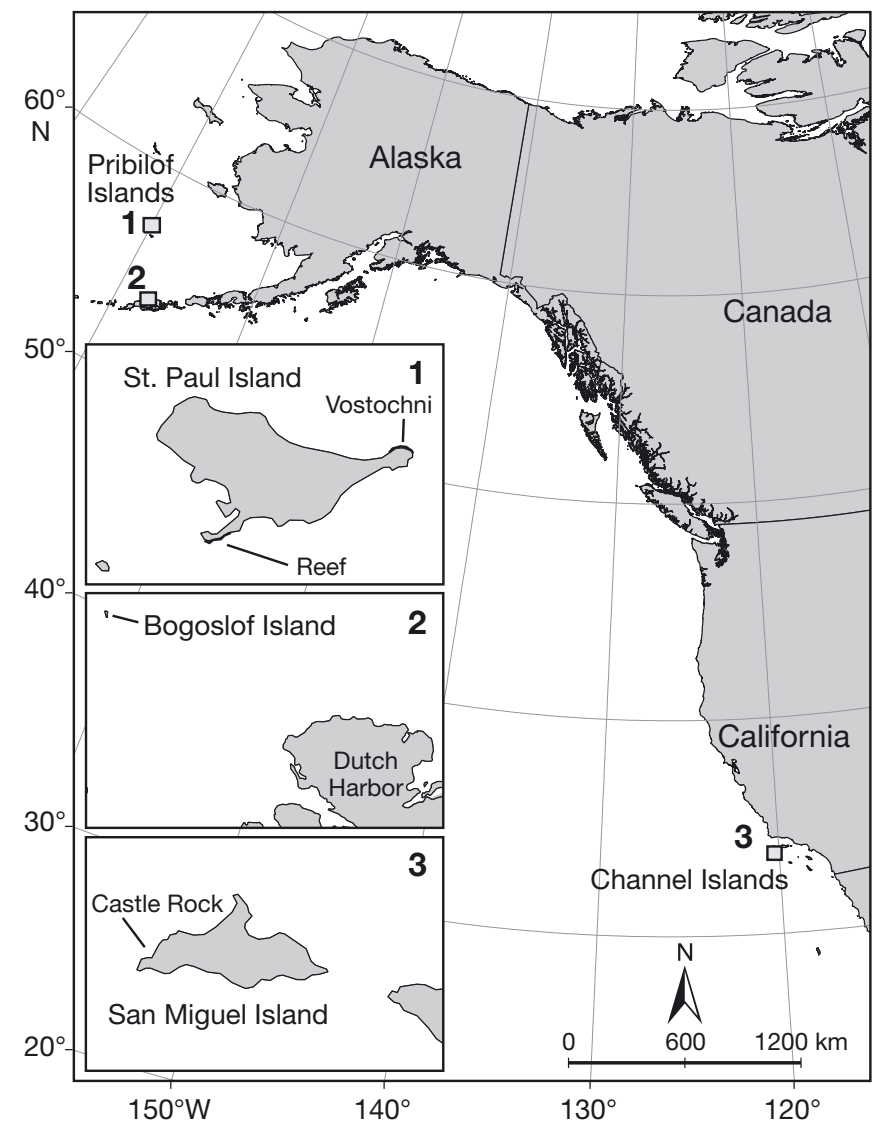

Fig. 1. Location of northern fur seal rookeries where fur, blood, and fecal samples were collected: (1) Reef and Vostochni rookeries on St. Paul Island $\left(57.18^{\circ} \mathrm{N}, 170.27^{\circ} \mathrm{W}\right)$; (2) Bogoslof Island $\left(53.93^{\circ} \mathrm{N}, 168.03^{\circ} \mathrm{W}\right)$; and (3) Castle Rock off San Miguel Island $\left(34.03^{\circ} \mathrm{N}, 120.44^{\circ} \mathrm{W}\right)$
Guard hair was clipped as close to the underfur as possible. Samples were placed in envelopes until further processing in the laboratory. Blood samples were obtained from the dorsal side of the rear flipper using a 21-gauge butterfly needle and placed directly into Vacutainer tubes. Plasma and red blood cells (RBCs) were collected from tubes with sodium heparin, which is an anticlotting agent that does not alter isotopic signatures (Hobson et al. 1997b). The tubes were centrifuged for $10 \mathrm{~min}$. Between 1 and $2 \mathrm{ml}$ of each blood component was decanted into a cryovial and frozen in $\mathrm{a}-40^{\circ} \mathrm{C}$ freezer for later laboratory processing.

In July 2006, fecal samples were opportunistically collected on Castle Rock, which is an islet $\sim 1 \mathrm{~km}$ northwest of SMI. Scats are usually collected on Castle Rock rather than on mainland SMI during the summer breeding season because samples are more accessible and collections result in less disturbance. Recent studies have indicated that adult females from SMI and Castle Rock forage in the same areas; thus, it is assumed that they are feeding on the same prey species (NMML unpubl. data). Scats were collected at Reef and Vostchoni rookeries on SPI in September 2006 and on BI in September 2007. At all locations, we assumed that scats collected on the rookery primarily represent the diet of adult females because territorial males fast during the breeding season. Juvenile animals arrive later in the season than adults and typically utilize areas that are separate from the breeding sites. Scat samples were stored in plastic bags and frozen for later processing.

Stable isotope analysis. In the laboratory, fur samples were put into scintillation vials and cleansed using a mild detergent solution, followed by a rinse of deionized (DI) water. Lipids were extracted using a 2:1 chloroform:methanol wash and another DI water rinse. Cleaned fur and frozen blood samples were placed in a lyophilizer and dried for 24 to $48 \mathrm{~h}$. The dried samples were then ground into a powder and homogenized using a glass rod (blood components) or mortar and pestle (fur). Samples were weighed $(1.0 \pm 0.2 \mathrm{mg})$ and sealed into $8 \times 5 \mathrm{~mm}$ tin capsules and analyzed using a continuous flow isotope ratio mass spectrometer (20-20 PDZ Europa) at the University of California Davis Stable Isotope Facility. The natural isotopic abundance in a sample is expressed in delta $(\delta)$ notation, $\delta^{13} \mathrm{C}$ or $\delta^{15} \mathrm{~N}=1000 \times\left[\left(\mathrm{R}_{\text {sample }} / \mathrm{R}_{\text {standard }}\right) \times 1\right]$, where $\mathrm{R}_{\text {sample }}$ and $\mathrm{R}_{\text {standard }}$ are the ${ }^{13} \mathrm{C} /{ }^{12} \mathrm{C}$ or ${ }^{15} \mathrm{~N} /{ }^{14} \mathrm{~N}$ ratios of the sample and standard, respectively. The standards are Vienna-Pee Dee Belemnite limestone (V-PDB) for carbon and atmospheric $\mathrm{N}_{2}$ for nitrogen. The units are expressed in parts per mille (\%). Tissues within an individual were compared among each other using a blocked 1-way ANOVA. Within each tissue type, linear models (ANOVAs) were used to compare $\delta^{13} \mathrm{C}$ or $\delta^{15} \mathrm{~N}$ 
between age classes (juvenile-adult female in Alaska, pup-adult female in California) and among locations. Significance of the effects was tested using $t$-test at the $5 \%$ significance level. Statistical analyses were performed using the R Program Language ( $\mathrm{R}$ Development Core Team 2006).

Scat analysis. In the laboratory, scat samples were thawed and rinsed in nested sieves $(2.0,1.0$, and $0.5 \mathrm{~mm}$ ) or processed in a washing machine (Orr et al. 2003). Fish remains were stored dry in scintillation vials and cephalopod structures were stored in vials with $70 \%$ isopropanol. Prey remains were identified under a dissecting microscope to the lowest possible taxon using sagittal otoliths and skeletal remains from fishes and beaks from cephalopods. Otoliths, beaks, and diagnostic bones were identified using the reference collection at the National Marine Mammal Laboratory (Seattle, WA).

The importance of prey taxa was described using percent frequency of occurrence ( $\% \mathrm{FO})$, which was defined as:

$$
\% \mathrm{FO}_{i}=\frac{\sum_{k=1}^{S} O_{i k}}{S} \times 100
$$

where $O_{i k}=$ absence (0) or presence (1) of taxon $i$ in scat $k_{\text {; }}$ and $s=$ the total number of scats that contained identifiable prey remains. The adequacy of the sample size to describe the diet was determined by creating mean cumulative prey diversity curves ( $\pm 1 \mathrm{SD})$ based on the Shannon-Wiener $\left(H^{\prime}\right)$ index (Krebs 1999) following an approach proposed by Ferry \& Cailliet (1996), Ferry et al. (1997), and modified by CruzEscalona \& Turren (Centro Interdisciplinario de Ciencias Marinas - Instituto Politecnico Nacional, Mexico). Curves were created by implementing a Matlab routine that computes 500 random permutations from the original data. If the prey diversity curve reached an asymptote, we assumed that enough samples have been analyzed to characterize the diet. Distribution and life history patterns of the most frequently occurring prey were used to aid in the interpretation of $\delta^{13} \mathrm{C}$ and $\delta^{15} \mathrm{~N}$ values.

\section{RESULTS}

\section{Stable isotope analysis}

Stable isotope samples were collected from 36 adult females and 37 juveniles in Alaska, and 9 adult females and 7 pups on San Miguel Island during September and November 2006 (Table 1). We were unable to collect all tissue types from all animals at each location. All tissue types were collected from 32 adult females and 25 juveniles in Alaska, and 9 adult females and 6 pups on San Miguel Island during September and November 2006 (Table 1). Male and female data of juveniles and pups were pooled for analyses because sample sizes were not large enough to allow statistical comparisons between sexes.

\section{Within-individual variation}

The $\delta^{13} \mathrm{C}$ and $\delta^{15} \mathrm{~N}$ values differed among tissues within individuals (blocked ANOVA: $F=40.75$, df $=2$, $\mathrm{p}<0.001$ for $\delta^{13} \mathrm{C}_{\text {; }}$ and $F=12.99$, df $=2, \mathrm{p}<0.001$ for $\delta^{15} \mathrm{~N}_{i}$ Fig. 2). Post-hoc analysis indicated no differences in mean $\delta^{13} \mathrm{C}$ values among plasma and RBCs; however, fur had significantly higher mean $\delta^{13} \mathrm{C}$ values than the blood components (Tukey's HSD: for all com-

Table 1. Number of samples obtained from northern fur seals at St. Paul, Bogoslof and San Miguel Islands for stable isotope analyses during 2006 by age class and tissue type. Numbers in parentheses indicate sample sizes used to compare tissue types within individuals. Adult samples were from females only. Juvenile and pup samples were collected from both males and females. RBC: red blood cells

\begin{tabular}{|lcccc|}
\hline Location & Age class & Fur & Plasma & RBC \\
\hline St. Paul (Reef) & Adult & 10 & 10 & 10 \\
& Juvenile & $14(13)$ & 13 & $14(13)$ \\
St. Paul (Vostochni) & Adult & $6(5)$ & $6(5)$ & $7(5)$ \\
& Juvenile & 7 & 7 & 7 \\
Bogoslof & Adult & 17 & $19(17)$ & $19(17)$ \\
& Juvenile & $8(5)$ & $9(5)$ & $9(5)$ \\
San Miguel & Adult & $10(9)$ & 9 & 9 \\
& Pup & $7(6)$ & $7(6)$ & $7(6)$ \\
\hline
\end{tabular}

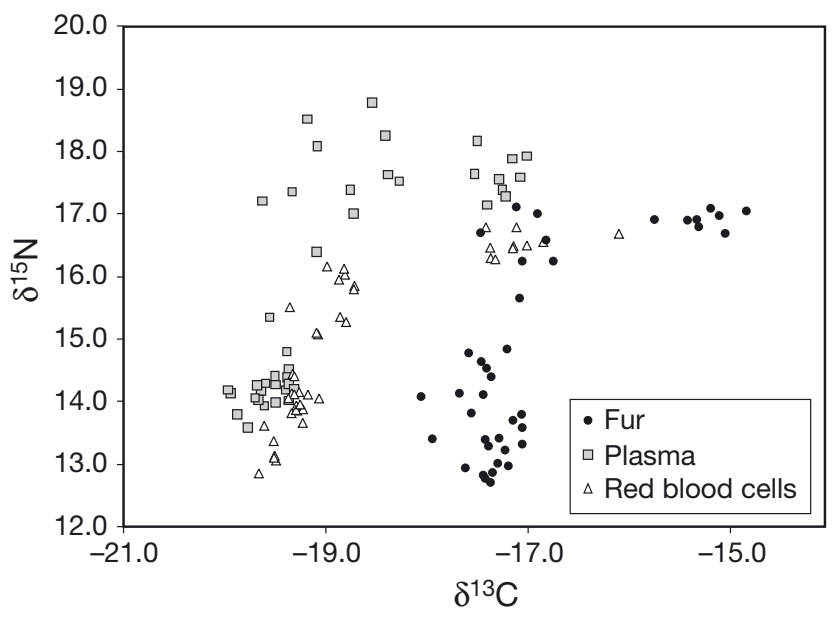

Fig. 2. Callorhinus ursinus. Relationship between $\delta^{13} \mathrm{C}$ and $\delta^{15} \mathrm{~N}$ of fur and blood tissues collected from adult female northern fur seals at St. Paul, Bogoslof, and San Miguel Islands during 2006. Pup and juvenile values were excluded for clarity but exhibited a pattern similar to that of adult females 
parisons, $p<0.001)$. There were no differences in mean $\delta^{15} \mathrm{~N}$ values between fur and RBCs; however, mean $\delta^{15} \mathrm{~N}$ values of fur and RBCs were significantly lower than those of plasma (Tukey's HSD: for all comparisons, $\mathrm{p}<0.001$ ).

\section{Inter-location variation}

All tissues of adults and pups collected at SMI had significantly higher mean $\delta^{13} \mathrm{C}$ values than any of the samples collected at Alaskan locations ( $t$-test: for all comparisons, $\mathrm{p}<0.01$; Fig. 3). Adults at BI had significantly lower plasma $\delta^{13} \mathrm{C}$ values compared to adults at Reef and Vostochni ( $t$-test: for all comparisons, p < 0.01), and lower RBC $\delta^{13} \mathrm{C}$ values compared to adults at Vostochni ( $t$-test, $\mathrm{p}<0.01)$. Stable carbon isotope patterns of juveniles were generally similar to those of adults (Fig. 3). Juveniles at Reef had significantly higher fur $\delta^{13} \mathrm{C}$ values than those at BI ( $t$-test, $\left.\mathrm{p}<0.01\right)$. Juveniles at Vostochni had significantly lower RBC $\delta^{13} \mathrm{C}$ values than those at Reef or BI ( $t$-test: for all comparisons, $\mathrm{p}<0.05$ ).

For adult females, we found similar patterns in $\delta^{15} \mathrm{~N}$ values for all tissue types (Fig. 3). Adult females at SMI
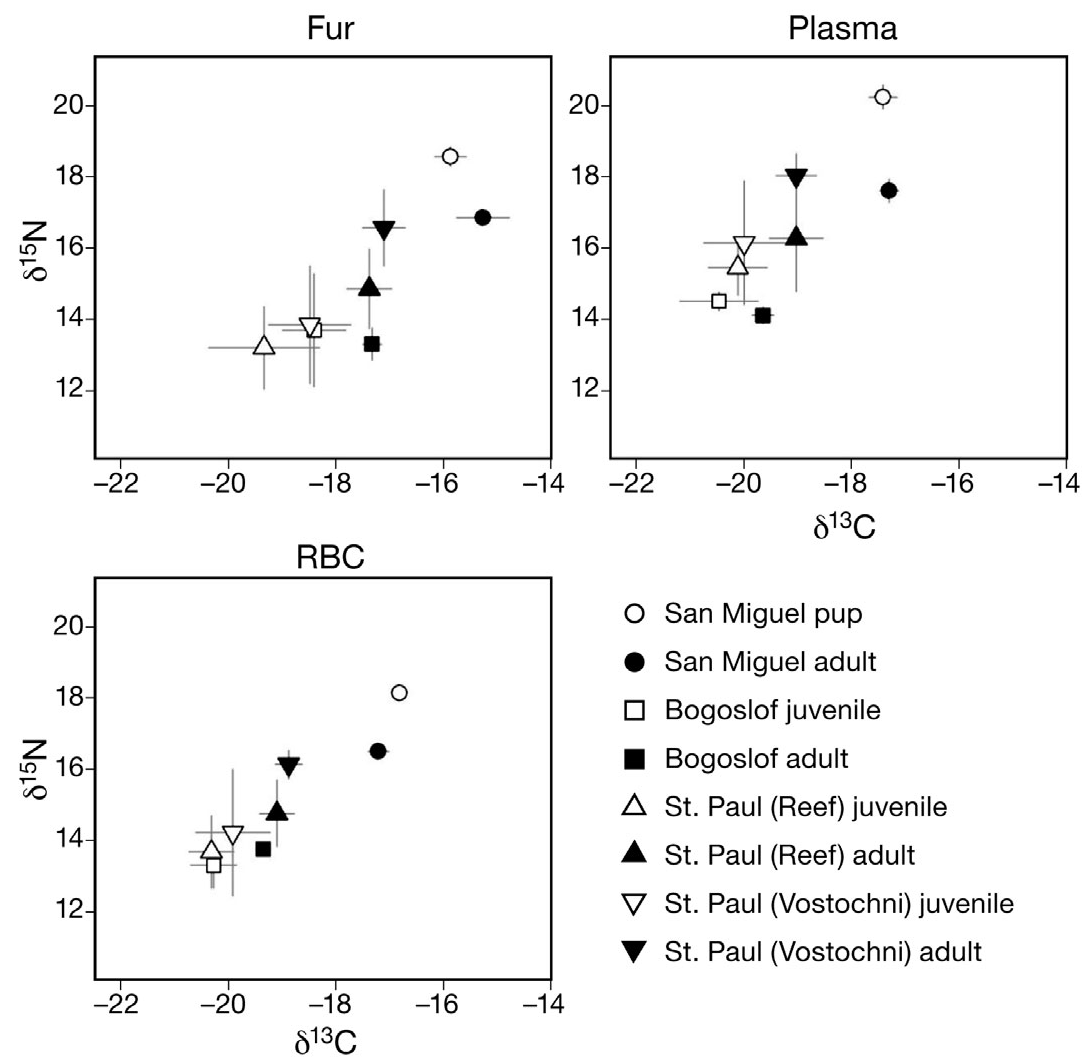

O San Miguel pup

- San Miguel adult

$\square$ Bogoslof juvenile

- Bogoslof adult

$\triangle$ St. Paul (Reef) juvenile

$\Delta$ St. Paul (Reef) adult

$\nabla$ St. Paul (Vostochni) juvenile

$\nabla$ St. Paul (Vostochni) adult

Fig. 3. Callorhinus ursinus. Relationship between mean $\delta^{13} \mathrm{C}$ and $\delta^{15} \mathrm{~N}$ of tissues collected from northern fur seals of various age classes at 4 rookery sites during 2006. Error bars: mean \pm 1 SD. RBC: red blood cells and Vostochni rookeries had the highest mean $\delta^{15} \mathrm{~N}$ values (regardless of tissue). Their $\delta^{15} \mathrm{~N}$ values were not significantly different from each other, but were significantly higher than those of adult females at the other rookeries ( $t$-test: for all comparisons, $p<0.01$; Fig. 3). Adult females at Reef had intermediate $\delta^{15} \mathrm{~N}$ values, which were significantly higher than those of adult females at BI ( $t$-test: for all comparisons, $\mathrm{p}<0.01$; Fig. 3). For juveniles, mean $\delta^{15} \mathrm{~N}$ values of all tissue types exhibited a similar pattern as those of adult females (Fig. 3). However, juveniles at BI had significantly lower RBC $\delta^{15} \mathrm{~N}$ values than those on Vostochni ( $t$-test, $\mathrm{p}<0.05$ ), and significantly lower plasma $\delta^{15} \mathrm{~N}$ values than juveniles at both SPI sites ( $t$-test: for all comparisons, $\mathrm{p}<0.01$ )

\section{Age-class variation}

There were significant differences in mean $\delta^{13} \mathrm{C}$ values between immature and adult animals at all sites (Fig. 3). Pups had significantly higher mean RBC $\delta^{13} \mathrm{C}$ values and significantly lower mean fur $\delta^{13} \mathrm{C}$ values than adults at SMI ( $t$-test, $\mathrm{p}=0.04)$. Juveniles had significantly lower mean $\delta^{13} \mathrm{C}$ values than adults for all tissue types at all Alaska sites ( $t$-test: for all comparisons, $\mathrm{p}<0.01$ ).

The relationship in $\delta^{15} \mathrm{~N}$ values between age classes was the same for all tissue types. Pups at SMI had significantly higher mean $\delta^{15} \mathrm{~N}$ values than adults ( $t$-test: for all comparisons, p < 0.01). Juveniles at Reef and Vostochni had significantly lower mean $\delta^{15} \mathrm{~N}$ values than adults ( $t$-test: for all comparisons, $\mathrm{p}<0.05$ ). There were no differences in mean $\delta^{15} \mathrm{~N}$ values between juveniles and adults at BI.

\section{Scat analysis}

One day of collection at each site yielded 170 scats that had identifiable prey remains: Reef ( $\mathrm{n}=28)$, Vostochni (n = 74), BI ( $\mathrm{n}=41)$, and Castle Rock, SMI ( $\mathrm{n}=27)$. The minimum number of samples needed to adequately describe diet varied by location; however, the mean cumulative prey diversity curves reached an asymptote, indicating that enough samples had been collected at the 4 rookeries (Fig. 4). For all locations combined, we identified at least 27 prey species from 17 families, which in- 

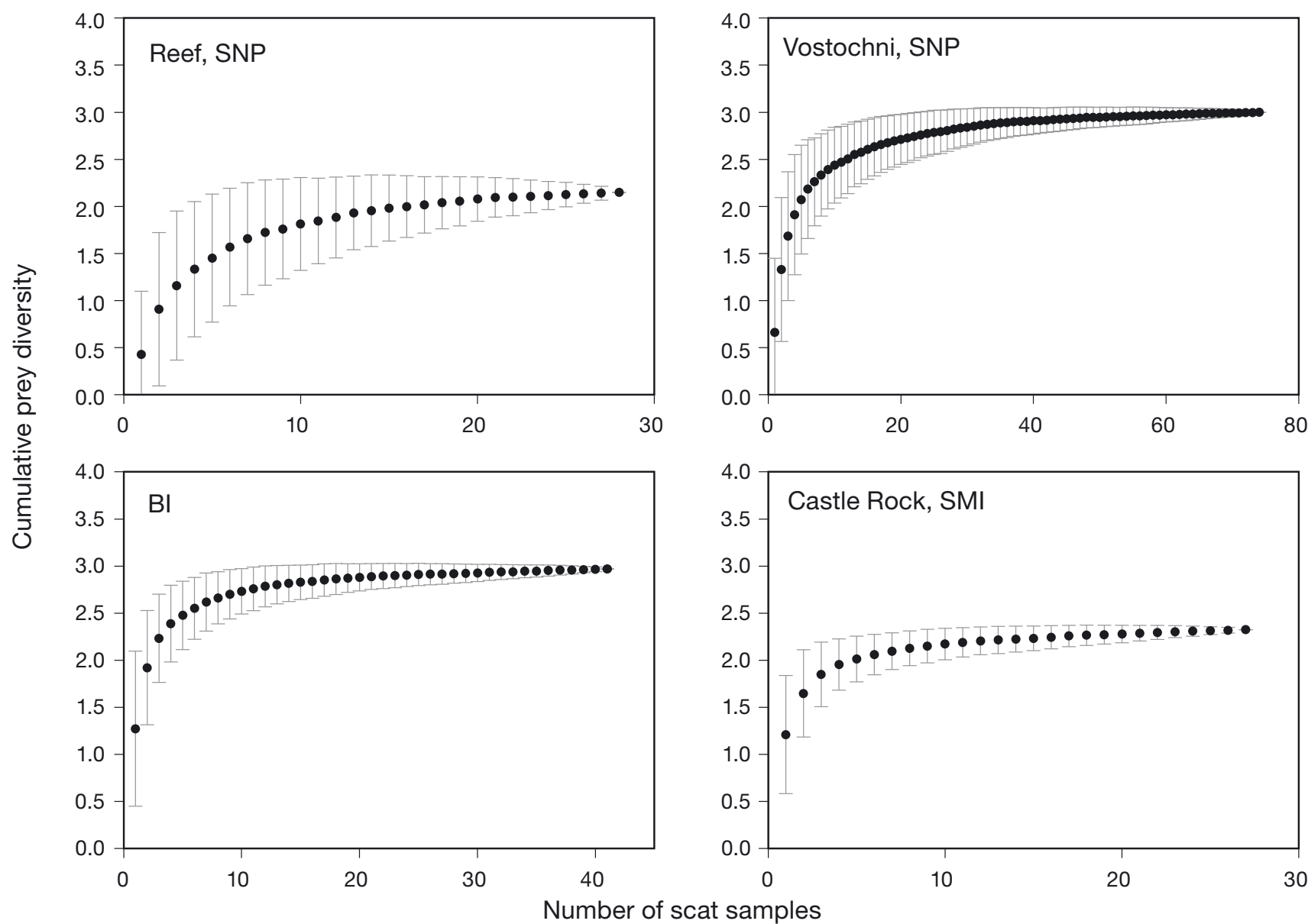

Fig. 4. Callorhinus ursinus. Mean cumulative prey diversity curves for northern fur seal scat samples collected at 4 rookeries (Reef and Vostochni on St. Paul Island [SNP], Bogoslof Island [BI], and Castle Rock off San Miguel Island [SMI]) during 2006 or 2007. Error bars: mean $\pm 1 \mathrm{SD}$. Cumulative prey diversity is based on the Shannon-Wiener $\left(H^{\prime}\right)$ index

cluded 22 fishes, 4 cephalopods, and 1 worm (Table 2). The relative importance of each prey taxon was determined using \%FO (Table 3). Walleye pollock (Theragra chalcogramma) dominated the diet on both Reef $(89.3 \%)$ and Vostochni (68.9\%). Other frequently occurring prey $(>5.0 \%)$ on both rookeries included $\mathrm{Pa}-$ cific herring (Clupea pallasi; $>14.0 \%$ ), Pacific salmon (Oncorhynchus spp.; $>17 \%$ ) and Atka mackerel (Pleurogrammus monopterygius; $>6.0 \%$ ); lanternfishes (myctophids; $10.7 \%$ ) on Reef rookery; and Pacific sand lance (Ammodytes hexapterus; 5.4\%), three-spine stickleback (Gasterosteus aculeatus; $5.4 \%$ ), Irish lord (Hemilepidotus spp.; $5.4 \%$ ) and gonatid squid (Gonatus madokai and/or G. middendorffi; $5.4 \%$ ) on Vostochni rookery. BI was characterized by high occurrences of off-shelf nekton, including gonatid squid (primarily Gonatopsis borealis, Berryteuthis magister, G. onyx, and G. tinro; $73.2 \%$ ) and northern smoothtongue (Leuroglossus schmidti; 73.2\%). SMI had high occurrences of northern anchovy (Engraulis mordax;
92.6\%), Pacific hake (Merluccius productus; $55.6 \%$ ), Pacific sardine (Sardinops sagax; 51.9\%), market squid (Loligo opalescens; $22.2 \%$ ) and rockfishes (Sebastes spp.; $7.4 \%$ ).

\section{DISCUSSION}

\section{Within-individual variation}

Mean $\delta^{13} \mathrm{C}$ values of fur were more enriched compared to those of the blood components. These results were similar to earlier studies of other pinniped species (Hobson et al. 1996, Hobson et al. 1997a, Lesage et al. 2002, Zhao et al. 2006). Variation in $\delta^{13} \mathrm{C}$ values among tissues of an individual may reflect temporal shifts in diet and/or habitat use or may relate to differences in the amino acid composition or lipid content of the tissues (Kurle 2002, Zhao et al. 2006). If the variation is due to the latter, it should be noted that blood contains 
Table 2. Callorhinus ursinus. Species and families of prey found in northern fur seal scat samples collected from St. Paul, Bogoslof, and San Miguel (Castle Rock) Islands. Samples from St. Paul and San Miguel Island sites were obtained in 2006, while those from Bogoslof Island were obtained in 2007

\begin{tabular}{|c|c|c|}
\hline Family & Species & Common name \\
\hline \multicolumn{3}{|l|}{ Fishes } \\
\hline Ammodytidae & Ammodytes hexapterus & Pacific sand lance \\
\hline Bathylagidae & $\begin{array}{l}\text { Bathylagus ochotensis } \\
\text { Leuroglossus schmidti }\end{array}$ & $\begin{array}{l}\text { Popeye blacksmelt } \\
\text { Northern smoothtongue }\end{array}$ \\
\hline Clupeidae & $\begin{array}{l}\text { Clupea harengus } \\
\text { Sardinops sagax }\end{array}$ & $\begin{array}{l}\text { Pacific herring } \\
\text { Pacific sardine }\end{array}$ \\
\hline Cottidae & $\begin{array}{l}\text { Cottid spp. } \\
\text { Hemilepidotus spp. }\end{array}$ & $\begin{array}{l}\text { Sculpin } \\
\text { Irish lord }\end{array}$ \\
\hline Engraulidae & Engraulis mordax & Northern anchovy \\
\hline Gadidae & $\begin{array}{l}\text { Gadus macrocephalus } \\
\text { Merluccius productus } \\
\text { Theragra chalcogramma }\end{array}$ & $\begin{array}{l}\text { Pacific cod } \\
\text { Pacific hake } \\
\text { Walleye pollock }\end{array}$ \\
\hline Gasterosteidae & Gasterosteus aculeatus & Three-spine stickleback \\
\hline Hexagrammidae & Pleurogrammus monopterygius & Atka mackerel \\
\hline Myctophidae & $\begin{array}{l}\text { Myctophid spp. } \\
\text { Nannobrachium regale } \\
\text { Stenobrachius leucopsarus } \\
\text { Symbolophorus californiensis }\end{array}$ & $\begin{array}{l}\text { Lanternfish } \\
\text { Pinpoint lampfish } \\
\text { Northern lampfish } \\
\text { Bigfin lanternfish }\end{array}$ \\
\hline Myxinidae & Myxinid & Hagfish \\
\hline Osmeridae & Mallotus villosus & Capelin \\
\hline Salmonidae & Oncorhynchus spp. & Pacific salmon \\
\hline Scorpaenidae & Sebastes spp. & Rockfish \\
\hline Trichodontidae & Trichodon trichodon & Pacific sandfish \\
\hline \multicolumn{3}{|l|}{ Cephalopods } \\
\hline Gonatidae & $\begin{array}{l}\text { Gonatid } \\
\text { Gonatopsis spp. }\end{array}$ & Gonatid squid \\
\hline Loliginidae & Loligo opalescens & Market squid \\
\hline Octopodidae & Octopus rubescens & East Pacific red octopus \\
\hline \multicolumn{3}{|l|}{ Other } \\
\hline $\begin{array}{l}\text { Class: Polychaeta } \\
\text { (polychaete worm) }\end{array}$ & - & - \\
\hline
\end{tabular}

serum albumins, which are the most abundant blood plasma proteins that serve as carriers of free fatty acids among other molecules (Lehninger 1982). Lipids have proportionally less ${ }^{13} \mathrm{C}$ than proteins, explaining why blood components have lower $\delta^{13} \mathrm{C}$ values compared to fur, which is primarily composed of proteins. Plasma has higher lipid concentrations that may result in lower $\delta^{13} \mathrm{C}$ values compared to RBCs (Nelson 1970, Kurle 2002). Lipids were removed from fur during sample preparation. However, fur has a different amino acid composition compared to blood. More specifically, fur and other keratinaceous tissues have glycine, which is ${ }^{13} \mathrm{C}$-enriched compared to most other amino acids. Therefore, there may have been differences in $\delta^{13} \mathrm{C}$ between fur and blood components that could not be ascribed to temporal shifts in foraging location by an individual. The variable lipid or amino acid content of tissues could bias $\delta^{13} \mathrm{C}$ values for blood components; however, the magnitude of this potential bias was not measured in this study.

Apart from being a metric of changes in dietary intake and trophic level at different temporal scales, differences in $\delta^{15} \mathrm{~N}$ values among tissues of an individual could also have resulted from differences in macromolecular composition (i.e. amino acids, lipids) of tissues (Kurle 2002, Zhao et al. 2006). Findings of several studies on captive birds and mammals indicate that isotope values of different tissues from the same individual vary in a systematic way, even when the animal is fed an isotopically monotonous diet (Tieszen et al. 1983, Sutoh et al. 1987, Hobson \& Clark 1993, Hobson et al. 1996, Kurle 2002, Lesage et al. 2002, De Smet et al. 2004, Zhao et al. 2006). Although lipids have inconsiderable influence on $\delta^{15} \mathrm{~N}$ values given their small composition of nitrogen, Kurle (2002) reported that differences in amino acid composition accounted for differences in $\delta^{15} \mathrm{~N}$ values among blood constituents in captive northern fur seals that were fed an isotopically homogeneous diet throughout the study. Unlike captive animals, wild northern fur seals usually do not have an isotopically homogeneous diet. However, isotopic patterns among tissues in this study were similar to those observed in captive marine mammal studies (e.g. Hobson et al. 1996, Lesage et al. 2002). Therefore, along with changes in fur seal diet (i.e. prey species, acquisition location), tissue composition and other physiological factors should be considered when interpreting differences in $\delta^{15} \mathrm{~N}$ and $\delta^{13} \mathrm{C}$ values among different tissues.

\section{Inter-location variation}

The fact that plasma and RBC values were different among islands indicates that fur seals segregate habitat throughout the breeding season. The $\delta^{13} \mathrm{C}$ values of plasma and RBCs were different at each island $\left(\delta^{13} \mathrm{C}\right.$ enrichment: $\mathrm{SMI}>\mathrm{SPI}>\mathrm{BI}$ ), which may denote that fur seals from these sites foraged in geographically distinct areas throughout the summer. The $\delta^{15} \mathrm{~N}$ and $\delta^{13} \mathrm{C}$ values of plasma reflect diet integrated approximately 
Table 3. Callorhinus ursinus. Percent frequency of occurrence $(\% \mathrm{FO}>5 \%)$ of prey taxa retrieved from northern fur seal fecal samples collected at 4 rookeries during 2006 or 2007 (Bogoslof). n: number of samples that had identifiable prey remains. Bold numbers indicate prey taxa with \%FO $>10 \%$

\begin{tabular}{|lrccc|}
\hline Prey taxa & $\begin{array}{c}\text { Reef } \\
(\mathrm{n}=28)\end{array}$ & $\begin{array}{c}\text { Vostochni } \\
(\mathrm{n}=74)\end{array}$ & $\begin{array}{c}\text { Bogoslof } \\
(\mathrm{n}=41)\end{array}$ & $\begin{array}{c}\text { Castle Rock } \\
(\mathrm{n}=27)\end{array}$ \\
\hline $\begin{array}{l}\text { Engraulis mordax } \\
\text { Leuroglossus schmidti }\end{array}$ & & & & $\mathbf{9 2 . 6}$ \\
Theragra chalcogramma & $\mathbf{8 9 . 3}$ & $\mathbf{6 8 . 9}$ & 9.8 & \\
Merluccius productus & & & & $\mathbf{5 5 . 6}$ \\
Sardinops sagax & & & & $\mathbf{5 1 . 9}$ \\
Loligo opalescens & & & & $\mathbf{2 2 . 2}$ \\
Gonatid squid & 3.6 & 5.4 & $\mathbf{7 3 . 2}$ & 3.7 \\
Clupea harengus & $\mathbf{1 4 . 3}$ & $\mathbf{2 7 . 0}$ & & \\
Oncorhynchus spp. & $\mathbf{1 7 . 9}$ & $\mathbf{1 8 . 9}$ & & \\
Gadid & 3.6 & $\mathbf{2 5 . 7}$ & 2.4 & 3.7 \\
Myctophid spp. & $\mathbf{1 0 . 7}$ & & $\mathbf{1 7 . 1}$ & \\
Pleurogrammus monopterygius & $\mathbf{1 4 . 3}$ & 6.8 & 2.4 & \\
Sebastes spp. & & & & \\
Ammodytes hexapterus & & 5.4 & & 3.7 \\
Gasterosteus aculeatus & & 5.4 & & \\
Hemilepidotus spp. & & 5.4 & & \\
Cottid spp. & & & & \\
\hline
\end{tabular}

1 to 2 wks prior to collection, whereas those of RBCs represent the diet of the prior few months (Hobson \& Clark 1993, Hilderbrand et al. 1996, Zhao 2002, Zhao et al. 2006); therefore, the stable isotope patterns were maintained for multiple foraging trips throughout the summer breeding season. The ${ }^{13} \mathrm{C}$-enriched values for individuals at SMI relative to those at the Alaska sites may be a reflection of latitudinal isotopic differences at the base of the food web $\left({ }^{13} \mathrm{C}\right.$-enrichment: lower > higher latitudes; Rau et al. 1982, Dunton et al. 1989, Goericke \& Fry 1994, Schell et al. 1998). The $\delta^{13} \mathrm{C}$ values of fur seals at BI and SPI did not follow the same latitudinal pattern. These patterns may have been affected by other factors including differences in foraging location (e.g. depth, distance from shore). The similarity in $\delta^{13} \mathrm{C}$ values between individuals at Reef and Vostochni rookeries on SPI may indicate an overlap in foraging habitats. Alternatively, if the animals foraged in different areas, there may not be sufficient geographical separation between those areas to result in dissimilar carbon isotope compositions.

Fur seals molt annually for an average of $15 \mathrm{wk}$ beginning in late July (Scheffer 1962, Scheffer \& Johnson 1963). Approximately $25 \%$ of the guard hair from the previous generation is thought to remain following the molt (Scheffer \& Johnson 1963). Thus, fur represents nutrients incorporated from the summer breeding season and, to a lesser extent, the previous winter migration and earlier molts. Adult females at the Alaska sites had similar mean fur $\delta^{13} \mathrm{C}$ values, which suggests that they migrate to the same general areas during winter months to feed. The mean fur $\delta^{13} \mathrm{C}$ values of Alaska females were lower than those of adult females at SMI, which suggests that they forage in different oceanic domains than SMI animals. The higher mean fur $\delta^{13} \mathrm{C}$ values of SMI adult females may reflect more coastal foraging than that of Alaskan adult females.

The habitat separation of animals from the different islands (discerned from stable carbon isotope ratios) in our study are supported by previous telemetry studies of northern fur seals. Studies conducted on both adult females and juvenile males at Alaska sites during the summer breeding season found differences in foraging habitat based on island and breeding colony (Robson et al. 2004, Sterling \& Ream 2004, Call et al. 2008). Adult females have been shown to exhibit a high degree of habitat fidelity on repeat foraging trips throughout the breeding season (Robson et al. 2004, Call et al. 2008). Fur seal foraging habitats have been characterized by unique marine environments that are defined by hydrographic domains associated with the continental shelf (Goebel et al. 1991, Robson et al. 2004, Sterling \& Ream 2004, Call et al. 2008). Adult females at BI generally take short foraging trips $(<50 \mathrm{~km})$ to deep offshore waters (Ream et al. 1999, NMML unpubl. data). Adult females and juvenile males at Vostochni typically forage over the continental shelf, and animals at Reef utilize both on-shelf and off-shelf habitats (Loughlin et al. 1987, Goebel et al. 1991, Sterling \& Ream 2004, Call et al. 2008). Postpartum females at SMI forage primarily in pelagic waters over the continental slope to the northwest of the island (Antonelis et al. 1990). No studies have been conducted on the foraging characteristics of juveniles or pups at SMI during the breeding season.

Data from historical pelagic collections of northern fur seals have been used to examine their winter migration (Kenyon \& Wilke 1953, Lander \& Kajimura 1982, Bigg 1990). However, these pelagic collections are biased towards nearshore waters. Telemetry studies indicated that adult female fur seals at SPI and BI travel to foraging areas in the subarctic-subtropical region of the central North Pacific and the coastal areas of the eastern North Pacific during the winter months (Ream et al. 2005, NMML unpubl. data). Adult females and recently weaned pups at SMI migrate northwards along the continental margin (Lea et al. 2009). During their winter migrations, it appears that adult females travel further offshore compared to pups 
(NMML unpubl. data; S. R. Melin, AFSC, pers. comm.). At the Alaskan sites, stable nitrogen isotope values followed the same pattern for all tissue types (i.e. ${ }^{15} \mathrm{~N}$ enrichment: Vostochni $>$ Reef $>$ BI). There were no differences in mean $\delta^{15} \mathrm{~N}$ values between individuals at SMI and Vostochni, implying that fur seals at these sites were feeding at a similar trophic level within their respective communities. The enriched $\delta^{15} \mathrm{~N}$ values of fur seals at SMI and Vostochni rookeries imply that these individuals were feeding at a higher trophic level than animals at Reef and BI. We did not measure diettissue fractionation and were therefore unable to discern specific prey consumed at each location using stable isotopes. Several studies (e.g. Kurle \& Worthy 2001) have determined the diet-tissue fractionation of several prey of fur seals; however, diet-tissue fractionation for many prey have not yet been determined (esp. for SMI prey). In order to use models, isotope values for most, if not all, prey are needed to provide accurate results. It was beyond the scope of this study to reconstruct the diet of fur seals at each location; rather, we provide a foundation for understanding resource use by these animals throughout their distribution.

The scat samples collected in our study also indicate differences in diet among the study sites. Dietary differences were associated with prey assemblages in specific hydrographic domains. Although walleye pollock was the dominant prey of fur seals at both Reef and Vostochni, there were other dietary differences among animals at these sites. Scats from Vostochni contained almost exclusively on-shelf species (e.g. walleye pollock, Pacific herring, Pacific sand lance, and sand fish), whereas samples collected at Reef contained both on-shelf (e.g. walleye pollock, Pacific herring) and off-shelf species (e.g. myctophids). Fur seal scats collected on BI were dominated by deep-water species that migrate to pelagic waters at night (e.g. bathylagids, myctophids, and squid species). No scats were collected on BI in 2006, but samples were collected in September 2007 and used for this study. Previous studies indicated that the composition of the most frequently occurring prey retrieved from fur seal scats at BI changes very little between years during the summer breeding season (NMML unpubl. data).

Remains from scats collected at Castle Rock (SMI) were primarily from epi- or mesopelagic schooling prey (e.g. Pacific hake, northern anchovy, Pacific sardine, market squid); however, bathypelagic prey were also identified (e.g. California smoothtongue, northern lampfish, blue laternfish). Scats were collected at Castle Rock $\sim 2$ mo prior to the collections at the Alaskan sites and $\sim 4$ mo before the collection of tissues for stable isotope analysis at SMI because of logistical factors. However, we assumed that the prey assemblages in the regions where fur seals fed did not change dramat- ically during inter-island scat collections, or between the time when scats were collected at Castle Rock and when tissues were sampled at SMI. Scat studies conducted opportunistically throughout the year on other pinniped species (e.g. California sea lions Zalophus californianus) foraging in the same region show similar prey assemblages (Antonelis et al. 1984, Antonelis et al. 1990, Melin 2002). Our results are corroborated by previous food habit studies that indicated dietary differences among conspecifics from different breeding sites associated with the same hydrographic domains (Sinclair 1988, Antonelis et al. 1997, Perez 1997, Zeppelin \& Ream 2006). Our findings are further supported by dive data from previous studies that described intraspecific foraging strategies depending on hydrographic domain. Goebel et al. (1991) found that fur seals foraging over deep waters tended to make shallow dives at night following the movement of the deep scattering layer. Fur seals foraging over the shelf made dives throughout the day and night and many of their dives reached the bottom.

\section{Age-class variation}

We observed significant differences in mean $\delta^{13} \mathrm{C}$ and $\delta^{15} \mathrm{~N}$ values between adult females and immature animals. At SMI, pups had lower mean $\delta^{13} \mathrm{C}$ values (except for RBCs) and higher mean $\delta^{15} \mathrm{~N}$ values than adult females. The difference in $\delta^{13} \mathrm{C}$ values between pups and adult females may be because pups still relied on their mothers for nutrition and were sustained on a lipid-rich milk diet, which is ${ }^{13} \mathrm{C}$-depleted in comparison to the relatively protein-rich piscivorous diet of their mothers (Tieszen et al. 1983, Tieszen \& Boutton 1988, Polischuk et al. 2001, Kurle 2002). The likely reason why pups had higher $\delta^{15} \mathrm{~N}$ values than adult females at SMI is again their reliance on their mothers for sustenance. The milk that pups consume is derived from remobilized body tissues of lactating females. Consequently, pups are essentially feeding on their mothers' tissues and thus feeding at a higher trophic level than older conspecifics.

Juveniles had lower mean $\delta^{13} \mathrm{C}$ values than adult females at all Alaska sites. All juvenile tissues had lower $\delta^{13} \mathrm{C}$ values compared to adult female tissues, indicating that these age classes were feeding in different areas during both the summer breeding season and the winter migration. Telemetry data indicated that during the breeding season, juvenile males at SPI typically utilized the same hydrographic domains as adult females from the same rookeries; however, juvenile males traveled further from the rookery and left for greater durations (Sterling \& Ream 2004). Adult females are constrained by having to return to shore to 
nurse their pups, which restricts trip duration and the distance they can travel. Juveniles and adult females may also partition habitat during the breeding season to reduce competition, or because of differences in the abundance and distribution of their respective prey. Low numbers of yearlings were found in early nearshore pelagic collections of northern fur seals, suggesting that both juvenile males and females remain farther offshore than adult females during the winter migration (Kenyon \& Wilke 1953, Bigg 1990). Likewise, recent satellite-telemetry studies on SPI indicated that juveniles remain in the Bering Sea for a greater duration before departing for the winter migration and travel farther offshore during the migration than adult females (NMML unpubl. data). Most of the juveniles sampled in this study were estimated to be 1 and $2 \mathrm{yr}$ olds. Individuals within this age group generally remain offshore in the eastern North Pacific Ocean, with only a few coming into the Pribilof Islands region near the end of the breeding season (Bigg 1990). Because we sampled near the end of the breeding season, juveniles may have only recently returned to the breeding rookeries and the difference in both $\delta^{13} \mathrm{C}$ and $\delta^{15} \mathrm{~N}$ values of the blood components may be indicative of time spent in both the North Pacific Ocean and around the Pribilof Islands.

Juveniles had lower mean $\delta^{15} \mathrm{~N}$ values than adult females at both SPI rookeries. Enriched $\delta^{15} \mathrm{~N}$ values of adult females compared to juveniles at SPI suggest that adult females are feeding at a higher trophic level than juveniles. Hobson et al. (1997a) also found that adult females had higher $\delta^{15} \mathrm{~N}$ values than juvenile northern fur seals. Additionally, Kurle \& Worthy (2001) found that juvenile male northern fur seals at the Pribilof Islands feed at higher trophic levels with increasing age, based on comparison of $\delta^{15} \mathrm{~N}$ isotope values from several tissues with different turnover times.

Intraspecific age differences in diet or foraging behaviors may be the result of several factors. For example, young animals may be physiologically or morphometrically underdeveloped compared to adults. Fur seals, like all air-breathing homeotherms that dive for aquatic prey, are constrained by their ability to store and transport oxygen at depth (in blood and muscles), and decrease the rate at which it is used (Burns 1999). Onboard oxygen stores scale to body mass (SchmidtNielson 1984, Kooyman 1985, 1989) and metabolism (Kleiber 1975). Because young animals are smaller, have higher mass-specific metabolic rates, and lower mass-specific body-oxygen stores, they are limited in their diving depths and durations compared to older conspecifics. Immature animals may not have the swimming speed or the mouthparts to capture adult prey. Additionally, young animals may have different nutritional requirements, insufficient experience, or may be avoiding competition with older conspecifics (Fowler et al. 2006). Shifts in diet or changes in foraging/diving behaviors with increasing age have been observed in other otariid pinnipeds including the Galápagos fur seal (Arctocephalus galapagoensis; Horning \& Trillmich 1997), New Zealand fur seal (A. forsteri; Page et al. 2006), Australian sea lion (Neophoca cinerea; Fowler et al. 2006), Steller sea lion (Eumetopias jubatus; Raum-Suryan et al. 2004, Pitcher et al. 2005), and California sea lion (Zalophus californianus; NMML unpubl. data).

There was no difference in mean $\delta^{15} \mathrm{~N}$ values between adult females and juveniles at BI. Adult females at BI take short foraging trips relative to SPI seals and forage at night on small diel vertically migrating pelagic prey species (NMML unpubl. data). BI scats had highest occurrences of bathylagid, myctophid, and squid species. During the day, many of these species reside at depths beyond the physiological limits of both adults and juveniles. At night, they migrate to surface waters and are presumably accessible to both juvenile and adult fur seals.

We were unable to use scats to determine differences in diet between immature animals (i.e. pups and juveniles) and adult females because scats collected on rookeries are assumed to be from adult females. However, the life history and distribution of dominant prey species found in scats of adult females support our stable isotope results. For example, pollock was the dominant prey at SPI. Pollock segregate in the water column by age, with younger individuals residing in the surface to mid water, and older pollock residing near the bottom (Bailey 1989). Adult female fur seals have greater physiological capabilities and thus have better access to older pollock residing at greater depths, whereas juveniles might be restricted in their dive depths or have a smaller gape width to capture larger prey; thus, they might be eating younger and smaller pollock that are higher in the water column. Larger, older pollock have higher $\delta^{15} \mathrm{~N}$ values compared to smaller, younger individuals (Kurle \& Worthy 2001).

\section{CONCLUSIONS}

By incorporating the use of traditional proxies (e.g. fecal analysis) and biochemical methods (e.g. stable isotope analysis), we were able to acquire a better understanding of the foraging ecology of differentaged Callorhinus ursinus from multiple locations. Whereas both methods have inherent biases, they were strengthened when used in combination. Information on the identity of prey taxa was obtained using scat analysis. Because we used dual stable isotope analysis of multiple tissues with differing turnover 
rates, we were able to infer changes in foraging patterns within an individual and between groups of animals over longer temporal and spatial scales. Our findings are supported by previous telemetry and diet studies. We did not collect scats from juveniles and did not measure diet-tissue isotopic discrimination; however, we believe our findings provide a valuable foundation for future study. This rangewide knowledge of foraging ecology allows us to assess the relative importance of different prey species and could ultimately provide insights into the impacts of changing environmental conditions, predation, and fisheries on fur seals. To provide a better resolution on the foraging ecology of wild populations, future studies should include the use of multiple techniques, the simultaneous collection of stable isotope data for both consumer and prey to validate diet results, and the collection of scats from different age classes.

Acknowledgements. We thank H. Ziel, R. Towell, K. Call, J. Thomason, and J. Sterling for assistance with fieldwork. We also thank E. Siek, S. Finneseth, J. Thomason, and W. Walker for assistance with scat and stable isotope analyses. D. Johnson provided statistical and graphics assistance. V. CruzEscalona produced the cumulative prey diversity curves. M.-A. Lea provided movement and distribution information for animals at SMI. This manuscript was improved by helpful comments from S. Melin, R. Ream, and J. Sterling. The study was conducted in accordance with National Marine Fisheries Service Permit \#7821708.

\section{LITERATURE CITED}

Antonelis GA, Perez MA (1984) Estimated annual food consumption by northern fur seals in the California Current. CCOFI Rep XXV:135-145

Antonelis GA, Fiscus CH, DeLong RL (1984) Spring and summer prey of California sea lions, Zalophus californianus, at San Miguel Island, California, 1978-79. Fish Bull 82: 67-76

Antonelis GA, Stewart BS, Perryman WF (1990) Foraging characteristics of female northern fur seals (Callorhinus ursinus) and California sea lions (Zalophus californianus). Can J Zool 68:150-158

Antonelis GA, Sinclair EH, Ream RR, Robson BW (1997) Interisland variation in the diet of female northern fur seals (Callorhinus ursinus) in the Bering Sea. J Zool (Lond) 242: 435-451

Arim M, Naya DE (2003) Pinniped diets inferred from scats: analysis of biases in prey occurrence. Can J Zool 81:67-73

Bailey KM (1989) Interaction between the vertical distribution of juvenile walleye pollock Theragra chalcogramma in the eastern Bering Sea, and cannibalism. Mar Ecol Prog Ser 53:205-213

Baker JD, Donohue MJ (2000) Ontogeny of swimming and diving in northern fur seal (Callorhinus ursinus) pups. Can J Zool 78:100-109

Bartholomew GA, Hoel LG (1953) Reproductive behavior of the Alaska fur seal. J Mammal 34:417-436

Bigg MA (ed) (1990) Migration of northern fur seals (Callorhinus ursinus) off western North America. Department of
Fisheries and Oceans, Can Tech Rep Fish Aquat Sci 1764, Nanaimo, BC, p 64

Bigg MA, Fawcett I (1985) Two biases in diet determination of northern fur seals (Callorhinus ursinus). In: Beddington JR, Beverton RJH, Lavigne DM (eds) Marine mammals and fisheries. George Allen and Unwin, London, p 284-291

> Bowen WD (2000) Reconstruction of pinniped diets: accounting for complete digestion of otoliths and cephalopod beaks. Can J Fish Aquat Sci 57:898-905

Boyd IL, Murray AWA (2001) Monitoring a marine ecosystem using responses of upper trophic level predators. J Anim Ecol 70:747-760

Burns JM (1999) The development of diving behavior in juvenile Weddell seals: pushing physiological limits in order to survive. Can J Zool 77:737-747

Burns JM, Trumble SJ, Castellini MA, Testa JW (1998) The diet of Weddell seals in McMurdo Sound, Antarctica as determined from scat collections and stable isotope analysis. Polar Biol 19:272-282

Burton RK, Koch PL (1999) Isotopic tracking of foraging and long-distance migration in northeastern Pacific pinnipeds. Oecologia 119:578-585

> Call KA, Ream RR, Johnson D, Sterling JT, Towell RG (2008) Foraging route tactics and site fidelity of adult female northern fur seal (Callorhinus ursinus) around the Pribilof Islands. Deep-Sea Res II 55: 1883-1896

> De Smet S, Balcaen A, Claeys E, Boeckx P, Van Cleemput O (2004) Stable carbon isotope analysis of different tissues of beef animals in relation to their diet. Rapid Commun Mass Spectrom 18:1227-1232

DeLong RL (1982) Population biology of northern fur seals at San Miguel Island, California. PhD dissertation, University of California, Berkeley, CA

Dunton KH, Saupe SM, Golikov AN, Schell DM, Schonberg SV (1989) Trophic relationships and isotopic gradients among Arctic and subarctic marine fauna. Mar Ecol Prog Ser 56:89-97

Ferry LA, Cailliet GM (1996) Sample size and data analysis: Are we characterizing and comparing diet properly? In: MacKinlay D, Shearer K (eds) Feeding ecology and nutrition in fish. Proc Symp Feeding Ecology and Nutrition in Fish. Int Cong Biology of Fishes. American Fisheries Society, Bethesda, MD, p 71-80

Ferry LA, Clark SL, Cailliet GM (1997) Food habits of spotted sand bass (Paralabrax maculatofasciatus, Serranidae) from Bahia de Los Angeles, Baja California. Bull South Calif Acad Sci 96:1-21

Fowler SL, Costa DP, Arnould JPY, Gales NJ, Kuhn CE (2006) Ontogeny of diving behaviour in the Australian sea lion: trials of adolescence in a late bloomer. J Anim Ecol 75:358-367

Fry B, Sherr EB (1984) $\delta^{13} \mathrm{C}$ measurements as indicators of carbon flow in marine and freshwater ecosystems. Contrib Mar Sci 27:13-47

Gannes LZ, Martinez del Rio C, Koch P (1998) Natural abundance variations in stable isotopes and their potential uses in animal physiological ecology. Comp Biochem Physiol 119A:725-737

Gelatt T, Lowry L (2008) Callorhinus ursinus. In: IUCN (2009) IUCN red list of threatened species, version 2009.1. Available at www.iucnredlist.org

Gentry RL, Holt JR (1986) Attendance behavior of northern fur seals. In: Gentry RL, Kooyman GL (eds) Fur seals: maternal strategies on land and at sea. Princeton University Press, NJ, p 41-60

Goebel ME, Bengtson JL, Delong RL, Gentry RL, Loughlin TR (1991) Diving patterns and foraging locations of female northern fur seals. Fish Bull 89:171-179 
Goericke R, Fry B (1994) Variations of marine plankton $\delta^{13} \mathrm{C}$ with latitude, temperature, and dissolved $\mathrm{CO}_{2}$ in the world ocean. Global Biogeochem Cycles 8:85-90

Gundmundson CJ, Zeppelin TK, Ream RR (2006) Application of two methods for determining diet of northern fur seals (Callorhinus ursinus). Fish Bull (US) 89:171-179

> Hilderbrand GA, Farley SD, Robbins CT, Hanley TA, Titus K, Servheen C (1996) Use of stable isotopes to determine diets of living and extinct bears. Can J Zool 74:2080-2088

Hirons A, Schell DM, Finney BP (2001) Temporal records of $\delta^{13} \mathrm{C}$ and $\delta^{15} \mathrm{~N}$ in North Pacific pinnipeds: inferences regarding environmental change and diet. Oecologia 129:591-601

Hobson KA, Clark RG (1993) Turnover of ${ }^{13} \mathrm{C}$ in cellular and plasma fractions of blood: implications for nondestructive sampling in avian dietary studies. Auk 110:638-641

$>$ Hobson KA, Welch HE (1992) Determination of trophic relationships within a high Arctic marine food web using $\delta^{13} \mathrm{C}$ and $\delta^{15} \mathrm{~N}$ analysis. Mar Ecol Prog Ser 84:9-18

Hobson KA, Schell DM, Renouf D, Noseworthy E (1996) Stable carbon and nitrogen isotopic fractionation between diet and tissues of captive seals: implications for dietary reconstructions involving marine mammals. Can J Fish Aquat Sci 53:528-533

Hobson KA, Sease JL, Merrick RL, Piatt JF (1997a) Investigating trophic relationships of pinnipeds in Alaska and Washington using stable isotope ratios of nitrogen and carbon. Mar Mamm Sci 13:114-132

Hobson KA, Gibbs HL, Gloutney ML (1997b) Preservation of blood and tissue samples for stable-carbon and stablenitrogen analysis. Can J Zool 75:1720-1723

Horning M, Trillmich F (1997) Ontogeny of diving behaviour in the Galápagos fur seal. Behaviour 134:1211-1257

Kelly JF (2000) Stable isotopes of carbon and nitrogen in the study of avian and mammalian trophic ecology. Can J Zool 78:1-27

Kenyon KW, Wilke F (1953) Migration of the northern fur seal, Callorhinus ursinus. J Mammal 34:86-98

Kirsch PE, Iverson SJ, Bowen WD (2000) Effect of diet on body composition and blubber fatty acids in captive harp seals (Phoca groenlandica). Physiol Biochem Zool 73:45-59

Kleiber M (1975) The fire of life, an introduction to animal energetics. Krieger Publishing, New York, NY

Kooyman GL (1985) Physiology without restraint in diving mammals. Mar Mamm Sci 1:166-178

Kooyman GL (1989) Diverse divers: physiology and behavior. Springer-Verlag, Berlin

Krebs CJ (1999) Ecological methodology, 2nd edn. AddisonWesley Educational Publishers, Menlo Park, CA

Kurle CM (2002) Stable-isotope ratios of blood components from captive northern fur seals (Callorhinus ursinus) and their diet: applications for studying the foraging ecology of wild otariids. Can J Zool 80:902-909

Kurle CM, Worthy GAJ (2001) Stable isotope assessment of temporal and geographic differences in feeding ecology of northern fur seals (Callorhinus ursinus) and their prey. Oecologia 126:254-265

Lander RH, Kajimura H (1982) Status of northern fur seals. In: Mammals in the seas, Vol 4. Small cetaceans, seals, sirenians, and otters. FAO Fish Ser 5(4):319-345

> Lea MA, Johnson D, Ream R, Sterling J, Melin S, Gelatt T (2009) Extreme weather events influence dispersal of naive northern fur seals. Biol Lett 5:252-257

Lehninger AL (1982) Principles of biochemistry. Worth Publishers, New York, NY

Lesage V, Hammill OM, Kovacs MK (2002) Diet-tissue fractionation of stable carbon and nitrogen isotopes in phocid seals. Mar Mamm Sci 18:182-193
Loughlin TR, Bengtson JL, Merrick RL (1987) Characteristics of feeding trips of female northern fur seals. Can J Zool 65: 2079-2084

Lucas FA (1899) The fur seals and fur-seal islands of the North Pacific Ocean, Part 3. Government Printing Office, Washington, DC, pp 59-68

Melin SR (2002) The foraging ecology and reproduction of the California sea lion (Zalophus californianus californianus). $\mathrm{PhD}$ thesis, University of Minnesota, MN

Melin SR, Orr AJ, DeLong RL (2007) The status of the northern fur seal population at San Miguel Island, California, 2004 and 2005. In: Testa JW (ed) Fur seal investigations, 2004-2005. NOAA Tech Memo NMFS-AFSC-174, US Department of Commerce, Washington, DC p 40-53

> Nelson G (1970) The lipid composition of the blood of marine mammals, I. Young elephant seals (Mirounga augustirostris) and harp seals (Pagophilus groenlandicus). Comp Biochem Physiol B 34:109-116

Newsome SD, Etnier MA, Aurioles-Gamboa D (2006) Using carbon and nitrogen isotope values to investigate maternal strategies in northeast Pacific otariids. Mar Mamm Sci 22:556-572

Orr AJ, Laake JL, Dhruv MI, Banks AS, DeLong RL, Huber HR (2003) Comparison of processing pinniped scat samples using a washing machine and nested sieves. Wildl Soc Bull 31:253-257

> Page B, McKenzie J, Sumner MD, Coyne M, Goldsworthy SD (2006) Spatial separation of foraging habitats among New Zealand fur seals. Mar Ecol Prog Ser 323:263-279

Perez MA (1997) Data on the diet of northern fur seal (Callorhinus ursinus) with tags identifying island of origin collected by the United States and Canada during 1958-74 in the North Pacific and Bering Sea. In: Sinclair EH (ed) NOAA Tech Memo NMFS-AFSC-86, US Department of Commerce, Washington, DC, p 99-132

Peterson RS (1966) Behaviour studies of Pacific seals and sea lions (Otariidae). Bull Mamm Soc Br Isles 26:14-15

Pierce GJ, Boyle PR (1991) A review of methods for diet analysis in piscivorous marine mammals. Oceanogr Mar Biol Annu Rev 29:409-486

Pitcher KW, Rehberg MJ, Pendleton GW, Raum-Suryan KL, Gelatt TS, Swain UG, Sigler MF (2005) Ontogeny of dive performance in pup and juvenile Steller sea lions in Alaska. Can J Zool 83:1214-1231

Polischuk SC, Hobson KA, Ramsay MA (2001) Use of stablecarbon and -nitrogen isotopes to assess weaning and fasting in female polar bears and their cubs. Can J Zool 79: 499-511

Porras-Peters H, Aurioles-Gamboa D, Cruz-Escalona VH, Koch PL (2008) Trophic level and overlap of sea lions (Zalophus californianus) in the Gulf of California, Mexico. Mar Mamm Sci 24:554-576

R Development Core Team (2006) R: a language and environment for statistical computing. R Foundation for Statistical Computing, Vienna, www.R-project.org

- Rau GH, Sweeney RE, Kaplan IR (1982) Plankton ${ }^{13} \mathrm{C}:{ }^{12} \mathrm{C}$ ratio changes with latitude: differences between northern and southern oceans. Deep-Sea Res 29:1035-1039

> Raum-Suryan KL, Rehberg MJ, Pendelton GW, Pitcher KW, Gelatt TS (2004) Development of dispersal, movement patterns, and haul-out use by pup and juvenile Steller sea lion (Eumetopias jubatus) in Alaska. Mar Mamm Sci 20: $823-850$

Ream RR, Baker JD, Towell RG (1999) Bogoslof Island studies, 1997. In: Sinclair EH, Robson BW (eds) Fur seal investigations, 1997. NOAA Tech Memo NMFS-AFSC-106, US Department of Commerce, Washington, DC, p 81-91 
Ream RR, Sterling JT, Loughlin TR (2005) Oceanographic influences on northern fur seal migratory movements. Deep-Sea Res II 52:823-843

Reeves RR, Stewart BS, Leatherwood S (1992) The Sierra Club handbook of seals and sirenians. Sierra Club Books, San Francisco, CA

Reeves RR, Stewart BS, Clapham PJ, Powell JA (2002) National Audubon Society guide to marine mammals of the world. Alfred A. Knopf, New York, NY

Reid K, Croxall JP (2001) Environmental response of upper trophic-level predators reveals a system change in an Antarctic marine ecosystem. Proc Biol Sci 268:377-384

Robson BW, Goebel ME, Baker JD, Ream RR and others (2004) Separation of foraging habitat among breeding sites of a colonial marine predator, the northern fur seal (Callorhinus ursinus). Can J Zool 82:20-29

Scheffer VB (1962) Pelage and surface topography of the northern fur seal. N Am Fauna 64:1-206

Scheffer VB, Johnson AM (1963) Molt in the northern fur seal. US Fish Wildl Serv Spec Sci Fish 450:1-34

Schell DM, Barnett BA, Vinette KA (1998) Carbon and nitrogen isotope ratios in zooplankton of the Bering, Chukchi and Beaufort Seas. Mar Ecol Prog Ser 162:11-23

Schmidt-Nielsen K (1984) Scaling. Why is animal size so important? Cambridge University Press, Cambridge

Sinclair EH (1988) Feeding habits of northern fur seals in the Eastern Bering Sea. MSc thesis, Oregon State University, Corvallis, OR

Sinclair EH, Loughlin TR, Pearcy W (1994) Prey selection by northern fur seals (Callorhinus ursinus) in the eastern Bering Sea. Fish Bull 92:144-156

Stabeno PJ, Schumacher JD, Ohtani K (1999) The physical oceanography of the Bering Sea. In: Loughlin TR, Ohani K (eds) Dynamics of the Bering Sea: a summary of physical, chemical and biological characteristics and a synopsis of research on the Bering Sea. AK-SG99-03. University of Alaska Sea Grant, Fairbanks, AK, p 1-28

Sterling JT, Ream RR (2004) At-sea behavior of juvenile male northern fur seals (Callorhinus ursinus). Can J Zool 82: 1621-1637

Editorial responsibility: Michael Castellini,

Fairbanks, Alaska, USA
Sutoh M, Koyama T, Yoneyama T (1987) Variations of natural ${ }^{15} \mathrm{~N}$ abundances in the tissues and digesta of domestic animals. Radioisotopes 36:74-77

Tieszen LL, Boutton TW (1988) Stable carbon isotopes in terrestrial ecosystems research. In: Rundel PW, Ehleringer JR, Nagy KA (eds) Stable isotopes in ecological research. Springer-Verlag, Berlin, p 167-195

Tieszen LL, Boutton TW, Tesdahl KG, Slade NA (1983) Fractionation and turnover of stable carbon isotopes in animal tissues: implications for $\delta^{13} \mathrm{C}$ analysis of diet. Oecologia 57:32-37

Towell RG, Ream RR, York AE (2006) Decline in northern fur seal (Callorhinus ursinus) pup production on the Pribilof Islands. Mar Mamm Sci 22:486-491

Vander Zanden MJ, Rasmussen JB (2001) Variation in $\delta^{15} \mathrm{~N}$ and $\delta^{13} \mathrm{C}$ trophic fractionation: implications for aquatic food web studies. Limnol Oceanogr 46:2061-2066

Wada E, Mizutani H, Minagawa M (1991) The use of stable isotopes for food web analysis. Crit Rev Food Sci Nutr 30: 361-371

> Yonezaki S, Kiyota M, Baba N, Koido T, Takemura A (2003) Size distribution of the hard remains of prey in the digestive tract of northern fur seal (Callorhinus ursinus) and related biases in diet estimation by scat analysis. Mamm Stud 28:97-102

> Yonezaki S, Kiyota M, Baba N (2008) Decadal changes in the diet of northern fur seal (Callorhinus ursinus) migrating off the Pacific coast of northeastern Japan. Fish Oceanogr $17: 231-238$

Zeppelin TK, Ream RR (2006) Foraging habitats based on the diet of female northern fur seals (Callorhinus ursinus) on the Pribilof Islands, Alaska. J Zool (Lond) 270:565-576

Zhao L (2002) Tracing amino acid metabolism of harbor seals (Phoca vitulina) using stable isotope techniques. $\mathrm{PhD}$ dissertation, University of Alaska, Fairbanks, AK

Zhao L, Castellini MA, Mau TL, Trumble SJ (2004) Trophic interactions of Antarctic seals as determined by stable isotope signatures. Polar Biol 27:368-373

Zhao LY, Schell DM, Castellini MA (2006) Dietary macronutrients influence ${ }^{13} \mathrm{C}$ and ${ }^{15} \mathrm{~N}$ signatures of pinnipeds: captive feeding studies with harbor seals (Phoca vitulina). Comp Biochem Physiol A Mol Integr Physiol 143:469-478

Submitted: December 11, 2009; Accepted: April 14, 2010 Proofs received from author(s): June 14, 2010 